\title{
Relationship between mercury levels and diet in Azores seabirds
}

\author{
L. R. Monteiro ${ }^{1, *}$, J. P. Granadeiro ${ }^{2,3}$, R. W. Furness ${ }^{3}$ \\ ${ }^{1}$ Departamento de Oceanografia e Pescas, Universidade dos Açores, P-9900 Horta, Portugal \\ ${ }^{2}$ Instituto da Conservação da Natureza, Rua Filipe Folque 46, $3^{\circ}, \mathrm{P}-1050$ Lisboa, Portugal \\ ${ }^{3}$ Ornithology Group, Institute of Biomedical and Life Sciences, Graham Kerr Building, University of Glasgow, \\ Glasgow G12 8QQ, United Kingdom
}

\begin{abstract}
Mercury concentrations were determined in feather and food samples from adults of 6 seabird species from the Azores archipelago. Mean concentrations ranged from 54 to $432 \mathrm{ng} \mathrm{g}^{-1}$ dry weight in food and 2.1 to $22.3 \mu \mathrm{g} \mathrm{g}^{-1}$ fresh weight in feather samples and were highly significantly and positively correlated. Significant seasonal differences in dietary mercury were also registered. Both feather and food mean concentrations were 4 -fold higher in seabirds feeding on mesopelagic prey than in those feeding predominantly on epipelagic prey. Concentrations in feathers were $150 \times$ those in food, which represents the highest methylmercury biomagnification factor reported for consumers in aquatic foodchains. These findings show that the inclusion of mesopelagic prey in seabird diet has an influence on mercury accumulation over and above that from trophic status and emphasises further the value of seabird feathers as monitors of the ecological hazards of mercury in marine ecosystems.
\end{abstract}

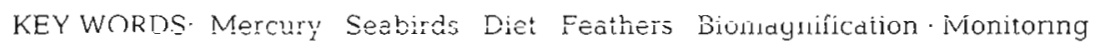

\section{INTRODUCTION}

Concentrations of mercury in the environment have increased many-fold since pre-industrial times (Pheiffer-Madsen 1981, Nater \& Gngal 1992, Swain et al. 1992, Thompson et al. 1992, Monteiro \& Furness 1997) as a result of anthropogenic emissions of gaseous mercury to the atmosphere (Mason et al. 1994, Hudson et al. 1995). The oceans play a major role in the global cycle of mercury (Fitzgerald 1989), and monitoring of the marine environment is a priority (EPMAP 1994). In this respect, biomonitors present good prospects for comprehensive appraisals of the abundance and bioavailability of mercury (Phillips 1980) because marine cycling of this metal includes many biologically-mediated processes (Mason \& Fitzgerald 1990, 1993). Seabirds, in particular, feature prominently as monitors of spatial and temporal patterns of mercury contamination in marine ecosystems as a result of growing knowledge of the metal dynamics in seabirds

•E-mail: monteiro@dop.uac.pt (reviews in Walsh 1990, Furness 1993, Monteiro \& Furness 1995).

Mercury dynamics in birds is best viewed as a multicompartment model involving ingestion from diet, uptake in the intestine, transport in blood, accumulation in internal tissues (e.g. muscle, liver, kidney), with redistribution to the plumage during feather growth, and elimination in eggs and excreta. The plumage contains over $70 \%$ of the mercury body burden in adults of a variety of bird species, despite forming less than $10 \%$ of total body weight (e.g. Honda et al. 1986 , Braune \& Gaskin 1987). Seabirds usually renew their plumage every year after breeding, when much of the dietary mercury accumulated in soft tissues between moults (most seabirds do not moult feathers over a 5 to 6 mo period; Ginn \& Melville 1983) is transferred into growing feathers. Feather samples have been widely used for the assessment of whole-bird mercury burdens due to the several methodological and conceptual advantages they have over other tissues: (1) feather sampling is easy and relatively non-invasive; (2) mercury is stably bound to feather keratins (Appelquist et al. 1984), thus special preservation procedures are not 
required, and the metal can be determined in historical samples: (3) feathers exhibit high concentrations with minor seasonal variations (Monteiro 1996); (4) concentrations in feathers correlate positively with those in internal tissues (Lewis \& Furness 1991, Thompson et al. 1991); (5) feather concentrations mostly reflect the uptake and storage of mercury during the breeding season, rather than short-term uptake (Furness et al. 1986, Honda et al. 1986, Braune \& Gaskin 1987).

Large variations in mercury levels among seabird species have been documented and attributed to a variety of proximate and ultimate factors such as trophic level, migratory habits, body size, life span, moult pattern and taxonomic influences on physiology (Walsh 1990, Monteiro \& Furness 1995). Dietary and feeding differences have been proposed as the best explanation for consistently low mercury levels in those species which feed predominantly upon crustaceans as compared to fish- and squid-eating species (Braune 1987, Honda et al. 1990, Lock et al. 1992); species feeding on other seabirds present some of the highest levels (Stewart et al. 1997). Moult-related constraints in mercury elimination from the body tissues to the plumage seem to lead to increased mercury levels in species with longer than annual moult cycles, like some albatrosses (Furness et al. 1986. Honda et al. 1990). Migratory habits might account for mercury levels in populations subjected to major differences in dietary mercury loadings at breeding and non-breeding grounds (Leonzio et al. 1986). Adult body size and life span seem to be irrelevant to mercury levels of adults in species so far studied, as size-dependency or age-related variations are lacking (e.g. Thompson et al. 1991, Burger et al. 1994). Potential taxonomic influences on physiology and mercury dynamics also seem to be unimportant in determining seabirds' mercury levels (Lock et al, 1992, Monteiro 1996). Besides all these factors, major inter-specific differences in mercury levels among fish- and squid-eating seabirds, notably high levels observed in some species at remote oceanic sites, are still poorly understood (Muirhead \& Furness 1988, Elliot et al. 1992, Monteiro et al. 1995). The elucidation of such differences is hampered by a major lack of information on mercury levels in seabirds' diets.

Ecological segregation in seabird communities may result in the feeding specialisation of some species on epipelagic prey (daytime depth $<200 \mathrm{~m}$ ) and of others on mesopelagic prey (daytime depth $>200 \mathrm{~m}$ but migrating into epipelagic zone at night). Additionally, increased concentrations of methylated mercury in seawater below the thermocline (Mason \& Fitzgerald 1990) result in enhanced bioaccumulation of mercury in mesopelagic organisms (Monteiro et al. 1996a). Hence, there is a rationale for hypothesising that major inter-specific differences in mercury levels among seabirds may be related to the relative importance of epipelagic and mesopelagic prey in their diet. To test this, we present here a comparison of mercury levels in diet and plumage in 6 seabirds from the Azores seabird assemblage. Such a comparison also provides a quantitative empirical appraisal of a dose-response relationship for mercury in wild birds.

\section{MATERIALS AND METHODS}

The study seabirds were selected according to their predominant dietary and feeding characteristics (Prince \& Morgan 1987, Monteiro et al. 1996b) in order to represent 2 dichotomous groups, one exploiting mesopelagic prey - Bulwer's petrel Bulweria bulwerii, hot-season Madeiran storm petrel Oceanodroma castro and cool-season Madeiran storm petrel (these $\bar{z}$ temporally segregated storm petrel forms are treated here as sibling species; Monteiro \& Furness 1998) and another exploiting epipelagic prey-Cory's shearwater Calonectris diomedea boreails, litile shedı water Puffinus assimilis baroli and common tern Sterna hirundo.

Feather sampling was undertaken between April 1993 and June 1995 at 3 multispecific seabird colonies (Vila, Praia and Baixo Islets) in the Azores $\left(36^{\circ}\right.$ to $39^{\circ} \mathrm{N}$, $25^{\circ}$ to $31^{\circ} \mathrm{W}$ ). Food samples were collected between March 1994 and January 1995 at the same 3 seabird colonies, except for some regurgitations by Cory's shearwater collected at Corvo Island (July 1994, $\mathrm{n}=$ 29). Sampling methods conformed to current guidelines for use of wild birds in research and sampling was carried out under appropriate licenses from local authorities. Birds were captured by hand on the ground (Cory's shearwater) or using mist-nets (petrels and little shearwater) and nest traps (common tern).

Contour feathers are the most representative for estimating whole-plumage mercury concentration in birds (Furness et al. 1986) and up to 10 ventral feathers were plucked from each of the live adults and placed in polyethylene bags prior to analysis for total mercury. For the common tern, diet composition was studied using pellets (made of undigested fish-bones regurgitated by adults and large chicks), and an estimate of food mercury concentration was derived from diet composition (Granadeiro et al. 1995) and mercury levels in prey fish (Monteiro et al. 1996a). Food samples from petrels and shearwaters consisted of spontaneous or induced regurgitations. Regurgitations were obtained from adults during the chick rearing periods (Monteiro et al. 1996b), except for some samples from Cory's shearwaters collected in March and all samples from little shearwaters that were collected in Septem- 
ber-October. Induced regurgitations were obtained using a stomach-pump (for Cory's shearwater) or a $50 \mathrm{ml}$ syringe (for little shearwater and the petrels), salt water and a catheter adequate to species size (Wilson 1984, Gales 1985). After examination for the presence of fish, squid or crustaceans, the excess salt water was removed and all solid remains preserved in $70 \%$ alcohol for later analysis. In the laboratory, the solid fraction was examined under a microscope, and all diagnostic hard parts (otholits, vertebrae, opercular, maxillary and pre-maxillary bones, cleitra, squid beaks, among others) were collected for identification of the prey species. When available, the edible component (hereafter designated as food, made mainly of muscle and accounting for over $80 \%$ of the whole net mass) was dehydrated to a constant weight in an oven at $50^{\circ} \mathrm{C}$, homogenised using a pestle and mortar and stored in air-tight polystyrene containers until analysis for total mercury.

Sample digestion and total mercury determination follow procedures described in detail elsewhere (Monteiro et al. 1995). Determinations were made by cold vapour atomic absorption spectrophotometry with a Perkin-Elmer Mercury Analyser System Coleman 50B. The limit of detection by the method, taken as twice the standard deviation of triplicate analysis at blank concentrations (Saltzman et al, 1983), was $10 \mathrm{ng}$, equivalent to $10 \mathrm{ng} \mathrm{g}^{-1}$ for a $1 \mathrm{~g}$ sample. Within- and between-laboratory quality control procedures were employed throughout the study period. Accuracy of the method (expressed as relative error) was within $10 \%$ and was monitored throughout the study with standards of inorganic mercury, reference materials (NRCC dogfish muscle DORM 1) and participation in the hair mercury interlaboratory comparison program undertaken by Health and Welfare Canada. Precision (or reproducibility) of the method (expressed as coefficient of variation) for duplicates within and between batches was generally within the usual $10 \%$ for total mercury determinations in biological samples (Saitzman et al. 1983). Interference with sensitivity due to the matrix and pre-treatment was assessed by the method of standard additions before the wet mineralisation digestion. Recoveries of added inorganic mercury averaged $99.8 \%(\mathrm{SE}=5.6, \mathrm{n}=8$ ) for feather samples and $69.3 \%$ ( $\mathrm{SE}=6.7, \mathrm{n}=8$ ) for food samples. The mean recovery in the food samples differed significantly from $100 \%$ (2-tailed $t$-test for comparison with a hypothesised mean of 100\%: $t_{7}=4.58, p<0.005$ ) and all food concentrations were corrected by this factor (i.e. multiplied by 1.44). Mercury concentrations are given in parts per million $\left(\mu g g^{-1}\right)$ on a fresh weight basis for feather samples (ppm, fw) and parts per billion (ng g $\mathrm{g}^{-1}$ ) on a dry weight basis (ppb, dw) for food samples. Concentrations in food may be converted to a fresh weight basis using an overall average percentage of moisture in whole fish of $68.8 \%$ (SE $=0.5 \%, n=$ 95) as a reference. Potential bias in mercury concentrations in food related to preservation in $70 \%$ alcohol is assumed to be negligible on the basis of testing with whole fish reported elsewhere (Monteiro et al. 1996a).

Statistical analysis followed standard procedures (Zar 1984). Data were tested for goodness of fit to a normal distribution using a Kolmogorov-Smirnov 1 sample test, and requirements of homogeneity of variances were determined using a Levene test. Where appropriate, parametric or non-parametric tests were employed.

\section{RESULTS}

A summary of diet composition of the study seabirds is shown in Table 1. These data validate the a priori separation into 2 groups based on the predominant origin of their prey, with the petrels exploiting mesopelagic prey and the shearwaters and the tern exploiting mostly epipelagic prey.

Mean mercury concentrations ranged from 54 to $432 \mathrm{ppb} \mathrm{dw}$ in food and from 2.1 to $22.3 \mathrm{ppm}$ fw in the breast feathers of the 6 study seabirds (Table 2). Mercury levels increase by about 4 -fold, in both food and feathers, in seabirds feeding on mesopelacgic prey compared to those feeding on epipelagic prey.

Mercury concentrations in food samples from Cory's shearwaters were highly significantly different (MannWhitney, $Z=5.77, \mathrm{p}<0.0001$ ) in the 2 periods consid ered (median, range): courtship/March (306, 136 to $721, n=17$ ) and chick-rearing/July-August $(48,13$ to $329, \mathrm{n}=51$ ). Mercury concentrations in food samples from the hot season (August) and cool season (December, January) Madeiran storm petrels (see Table 2) were significantly different ( $t$-test, $t_{40}=2.20, p<0.05$ ).

Mean mercury concentrations in feathers (ppm fw) and food (ppb dw) were highly significantly and positively correlated $\left(\mathrm{r}=0.968, F_{1,5}=73.6, \mathrm{p}<0.001\right)$. The relationship is described by the linear equation, which is constrained to pass through the origin (Fig. 1),

$\mathrm{Hg}$ in feathers $=0.0493 \pm 0.0057 \mathrm{SE} \times \mathrm{Hg}$ in food

The slope of this equation represents a food:feather biomagnification factor and assumes the value of $158 \pm$ $18 \mathrm{SE}$ when both concentrations are expressed in ppm $\mathrm{fw}$. Biomagnification factors for each species (Table 2), derived from the ratio of average mercury concentrations in feathers (ppm fw) and food (expressed in ppm $\mathrm{fw}_{i}$ based on a fraction of moisture in fish of 0.688 , Monteiro et al. 1996a), have an overall average of 149 ( $\mathrm{SE}=15, \mathrm{n}=6)$. These figures represent conservative estimates because food samples analysed for mercury 


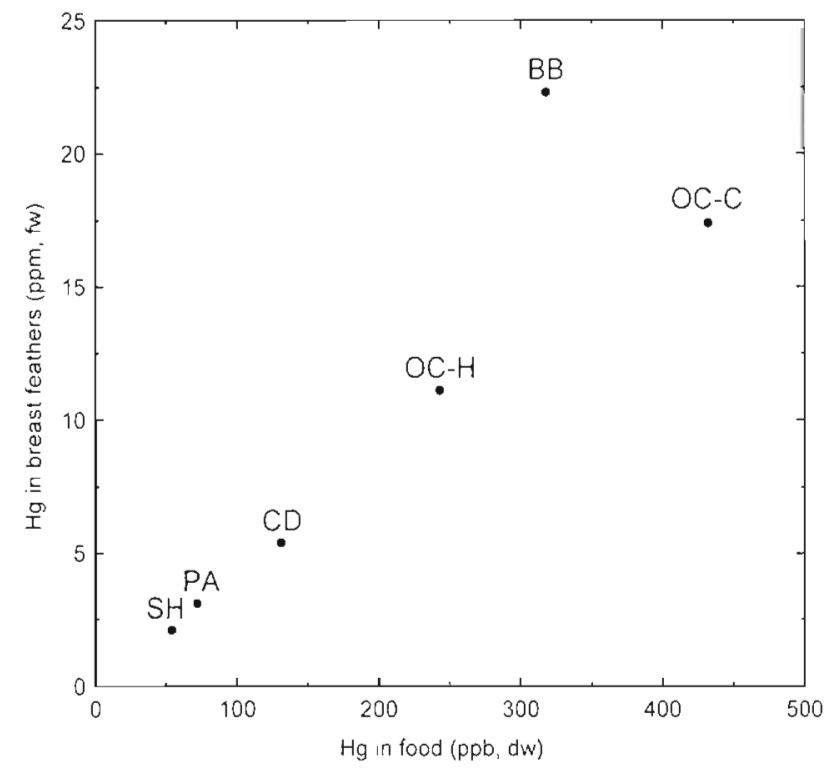

Fig. 1. Relationship between mean mercury concentrations in food and breast feathers of selected seabirds from the Azores. Species names are given in Table 1

The large seasonal differences in mercury concentrations observed in food samples from Cory's shearwaters indicate important seasonal variations in diet composition. Indeed, variations in the frequencies of occurrence of major prey in Cory's shearwater regurgitations were detected between March and July/ August, notably a decrease from 36.5 to $17.9 \%$ in the importance (by weight) of mesopelagic cephalopods (Granadeiro et al. 1998). However, a poor knowledge of mercury concentrations in prey organisms complicates the elucidation of the relationship between the observed seasonal variations in diet and dietary mercury concentrations. The observed mercury enrichment in March food samples may reflect feeding to a greater extent upon prey of mesopelagic origin and/or older fish, both presumed to have enhanced mercury levels (Monteiro et al. 1996a). Indeed, in March the period of darkness for foraging, i.e. when diel vertically migratory mesopelagic prey are available at the surface (Roe \& Badcock 1984, Perissinoto \& McQuaid 1992), is longer, and towards July/August the abundance of age 0 fish increases for some prey species (Pinho et al. 1995). Important intra-specific seasonal dietary shifts have been observed in other procellariiforms (e.g. Thompson \& Furness 1995, Warham 1996) and more research on this topic is warranted for the Cory's shearwater.

Differences in mercury concentrations between the 2 storm petrel forms are mirrored in food, feathers (this study) and eggs (Monteiro 1996), suggesting a noticeable variation in the consumption of mesopelagic prey, which appears to be more important for the cool-season form. Though full elucidation of this hypothesis is hampered by the lack of detailed dietary information, the hypothesis provides new insights into the understanding of ecological isolation between these 2 'presumed-sibling' species (Monteiro \& Furness 1998).

The high mercury levels found in the seabirds exploiting mesopelagic prey raise questions about the potential toxicity of mercury to those species, especially in view of rapidly increasing mercury contamination of the deep sea (Monteiro \& Furness 1997). Exposure levels inferred from mercury concentrations in the food of adult seabirds obtained in this study (means up to $432 \mathrm{ppb} \mathrm{dw}$ ) are well below the maximum reported avian non-observed-adverse-effectlevel (NOAEL) for external symptoms observed in adult zebra finches Poephila guttata subjected to a mercury dietary level of 2.5 ppm dw for $77 \mathrm{~d}$ (Scheuhammer 1988). Moreover, exposure levels observed in this study were also below the lowest-observedadverse-effect-level (LOAEL) in wild bird populations (Thompson 1996), with effects consisting of egg-laying and territorial-fidelity impairment in loons Gavia immer at mercury concentrations of 0.3 to $0.4 \mathrm{ppm} \mathrm{fw}$ in their prey (Barr 1986). Birds in general exhibit a relatively low susceptibility to methylmercury toxicity. This may result from the remarkable selectivity of methylmercury for the higher and evolutionarily more recent structures of the brain, such as the cortical areas. Indeed, vulnerability to methylmercury may not have been a problem throughout most of evolution, not until recent times when the brain developed in mammals and especially in primates (Clarkson 1994). Moreover, naturally high exposure of seabirds to mercury in the food chain may have led to the evolution of detoxification mechanisms related to the co-accumulation of selenium in these birds (Muirhead \& Furness 1988, Scheuhammer 1988)

The findings from this study contribute new insights into the potential of seabirds as monitors for mercury. First, mercury biomagnification (i.e. increase with trophic levels) high in the food chains involves primarily bioaccumulation of methylmercury (Riisgård \& Hansen 1990, Mason et al. 1995) and, in this respect, data presented here constitute the first quantitative field assessment of methylmercury enrichment associated with trophic transfer between fish/squid and seabirds. Because virtually all mercury in fish and bird feathers is methylmercury (>95\%; Thompson \& Furness 1989, Bloom 1992), the ratios of average feather: food total mercury concentrations indicate an average methylmercury enrichment factor over 150, while typical enrichment factors observed in field studies with zooplankton and fish muscle, including top predators, are of 2 to 10 (Windom et al. 1976. Watras \& Bloom 
1992. Monteiro unpubl data) This emphasises further the value of seabirds as monitors for mercury and particularly of bird feathers as monitoring units (cf. Furness et al. 1986). Second, ecological segregation in seabird communities has resulted, in many parts of the world, in feeding specialisation on epipelagic or mesopelagic organisms, especially among procellariiforms (Prince \& Morgan 1987). This offers a unique opportunity for easy and inexpensive monitoring of geographical and historical variations in mercury contamination. within and between these vertical compartments of marine ecosystems (Monteiro \& Furness 1997).

Acknowledgements. This research was supported by Junta Nacional de Investigação Científica through grants BD/2289/ 92-IG to L.R.M. and BD/1283/95 to J.P.G. and research contract STRDB/C/MAR/228/92. We thank the Direç̧ão Regional de Ambiente of the Azores for permits and Mário Laranjo and Luís Pires for assistance with sample preparation and mercury determinations.

\section{LITERATURE CITED}

Appelquist H, Asbirk S, Drabaek I (1984) Mercury monitoring: mercury stability in bird feathers. Mar Pollut Bull 15 $22-24$

Barr JF (1986) Population dynamics of the common loon (Gavia immer) associated with mercury-contaminated waters in northwestern Ontario. Canadian Wildlife Service, Occasional Paper No. 56

Bloom $N$ (1992) On the chemical form of mercury in edible fish and marine invertebrate tissue. Can J Fish Aquat Sci 49:1010-1017

Braune BM (1987) Comparison of total mercury levels in relation to diet and molt for nine species of marine birds. Arch Environ Contam Toxicol 16:217-224

Braune BM, Gaskin DE (1987) Mercury levels in Bonaparte's gull (Larus philadelphia) during Autumn moult in the Quoddy Region, New Brunswick, Canada. Arch Environ Contam Toxicol 16:539-549

Burger J, Nisbet ICT, Gochfeld M (1994) Heavy metal and selenium levels in feathers of known-aged common terns (Sterna hirundo). Arch Environ Contam Toxicol 26: $351-355$

Clarkson TW (1994) The toxicity of mercury and its compounds. In: Watras C.J, Huckabee JW (eds) Mercury pollution: integration and synthesis. Lewis Publishers, Boca Raton, p 631-641

Elliott JE, Scheuhammer AM, Leighton FA, Pearce PA (1992) Heavy metal and metallothionein concentrations in Atlantic Canadian seabirds. Arch Environ Contam Toxicol $22: 63-73$

EPMAP (Expert Panel on Mercury Atmospheric Processes) (1994) Mercury atmospheric processes: a synthesis report. Rep no. TR-10421.4. Electric Power Research Institute, Palo Alto, CA

Fitzgerald WF (1989) Atmospheric and oceanic cycling of mercury. In: Riley JP, Chester R (eds) Chemical oceanography, Vol 10. Academic Press, New York, p 151-186

Furness RW (1993) Birds as monitors of pollutants. In: Furness RW. Greenwood JJD (eds) Birds as monitors of environmental change. Chapman \& Hall, London, p 86-143

Furness RW. Muirhead SJ. Woodburn M (1986) Using bird feathers to measure mercury in the environment: relationships between mercury content and moult. Mar Pollut Bull $1: 27-30$

Gales RP (1985) Validation of the stomach-flushing technique for obtaining stomach contents of penguins. Ibis 129 : $335-343$

Ginn HB, Melville DS (1983) Moult in birds. British Trust for Ornithology, Tring

Granadeiro JP, Monteiro LR, Furness RW (1998) Diet and feeding ecology of Cory's shearwater Calonectes diomedea in the Azores, north-east Atlantic. Mar Ecol Prog Ser 166:267-276

Granadeiro JP, Monteiro LR, Furness RW, Silva MC (1995) The food of common terns Sterna hirundo in the Azores. l.n: Tasker ML (ed) Abstracts 5th Int Seabird Group Conference, Glasgow, 24-26 March 1995. The Seabird Group, Sandy, p 24

Honda $K$, Marcovecchio JE, Kan S, Tatsukawa R, Ogi $H$ (1990) Metal concentrations in pelagic seabirds from the North Pacific Ocean. Arch Environ Contam Toxicol 19: $704-711$

Honda K, Nacu T, Tatsukawa R (1986! Seasonal changes in mercury accumulation in the black-eared kite, Milvus migrans lineatus. Environ Pollut Ser A Ecol Biol 42: $325-334$

Hudson RJM, Gherini SA, Fitzgerald WF, Porcella DB (1995) Anthropogenic influences on the global mercury cycle: a model-based analysis. Wat Air Soil Pollut 80:265-272

Leonzio C. Fossi C. Focardi S (1986) Heavy metals and selenium variation in a migratory bird wintering in a mercurypolluted lagoon. Bull Environ Contam Toxicol 37:219-225

Lewis SA, Furness RW (1991) Mercury accumulation and excretion in laboratory reared black-headed gull Larus ridibundus chicks. Arch Environ Contam Toxicol 21: $316-320$

Lock JW, Thompson DR, Furness RW, Bartle JA (1992) Metal concentrations in seabirds of the New Zealand region. Environ Pollut 75:289-300

Mason RP, Fitzgerald WF (1990) Alkylmercury species in the equatorial Pacific. Nature 347:457-459

Mason RP, Fitzgerald WF (1993) The distribution and biogeochemical cycling of mercury in the equatorial Pacific Ocean. Deep Sea Res 40:1897-1924

Mason RP, Fitzgerald WF, Morel FMM (1994) The biogeochemical cycling of elemental mercury: anthropogenic influences. Geochim Cosmochim Acta 58:3191-3198

Mason RP, Reinfelder JR, Morel FMM (1995) Bioaccumulation of mercury and methylmercury. Wat Air Soil Pollut 80: 915-921

Monteiro LR (1996) Seabirds as monitors of mercury contamination in the Portuguese Atlantic. PhD thesis, University of Glasgow

Monteiro LR, Costa V, Furness RW, Santos RS (1996a) Mercury concentrations in prey fish indicate enhanced bioaccumulation in mesopelagic environments. Mar Ecol Prog Ser 141:21-25

Monteiro LR, Furness RW (1995) Seabirds as monitors of mercury in the marine environment. Wat Air Soil. Pollut 80 $851-870$

Monteiro LR, Furness RW (1997) Accelerated increase In mercury contamination in North Atlantic mesopelagic foodchains as indicated by time-series of seabird feathers Environ Toxicol Chem 16:2489-2493

Monteiro LR, Furness RW (1998) Speciation through temporal segregation of Madeiran storm petrel (Oceanodroma castrol populations in the Azores? Phil Trans R Soc Lond $B$ $353: 1-9$ 
Montelro LR, Furness RW, del Nevo AJ (1995) Mercury levels in seabirds from the Azores, Mid-North Atlantic Ocean. Arch Environ Contam Toxicol 28:304-309

Monterro LR, Ramos JA, Furness RW, del Nevo AJ (1996b) Movements, morphology, breeding, molt, diet and feeding of seabirds in the Azores. Colon Waterbirds 19:82-97

Muirhead SJ, Furness RW (1988) Heavy metal concentrations in tissues of seabirds from Gough Island, South Atlantic Ocean. Mar Pollut Bull 19:278-283

Nater EA, Grigal DF (1992) Regional trends in mercury distr1bution across the Grcat Lakes states, north central USA. Nature 358:139-141

Perissinoto R, McQuaid CD (1992) Land-based predator impact on vertically migrating zooplankton and micronekton advected to a Southern Ocean archipelago. Mar Ecol Prog Ser 80:15-27

Pheiffer-Madsen P (1981) Peat bog records of atmospheric mercury deposition. Nature 293:127-130

Phillips DJH (1980) Quantitative aquatic biological indicators: their use to monitor trace metal and organochlorine pollution. Applied Science Publishers Ltd, London

Pinho MR, Pereira JG, Rosa IS (1995) Caracterização da pesca do isco vivo da frota atuneira açoreana. Arquivos do DOP Série Estudos No. 2/95. University of Azores, Horta

Prince PA, Morgan RA (1987) Diet and feeding ecology of Procellariiforms. In: Croxall JP (ed) Seabirds: feeding ecology and role in marine ecosystems. Cambridge University Press, Cambridge, p 135-171

Riisgård HU, Hansen S (1990) Biomagnification of mercury in a marine grazing food-chain: algal cells Phaeodactylum tricornutum, mussels Mytilus edulis and flounders Platichthys flesus studied by means of a stepwise-reductionCVAA method. Mar Ecol Prog Ser 62:259-270

Roe HSJ, Badcock J (1984) The diel migrations within a mesopelagic community in the North East Atlantic, 5. Vertical migrations and feeding of fish. Prog Oceanogr 13: $389-4.24$

Saltzman BE, Yeager DW, Meiners BG (1983) Reproducibility and quality control in the analysis of biological samples for lead and mercury. Am Ind Hyg Assoc J 44:263-267

Scheuhammer AM (1988) Chronic dietary toxicity of methylmercury in the Zebra finch, Poephila guttata. Bull Environ Contam Toxicol 40:123-130

Editorial responsibility: Otto Kinne (Editor), Oldendorf/Luhe, Germany
Stewart FM, Phillips RA, Catry P, Furness RW (1997) The influence of age and diet on mercury concentrations in Shetland seabirds. Mar Ecol Prog Ser 151:237-244

Swain EB, Engstrom DR, Brigham ME, Henning TA, Brezonik PL (1992) Increasing rates of atmospheric mercury deposition in midcontinental North America. Science 257: $784-787$

Thompson DR (1996) Mercury in birds and terrestrial mammals. In Beyer WN, Heinz GW, Redman-Norwood AW (eds) Environmental contaminants in wildlife: interpreting tissue concentrations. Lewis Publishers, Boca Raton, p 341-356

Thompson DR, Furness RW (1989) Comparison of the levels of total and organic mercury in seabird feathers. Mar Pollut Bull 20:577-579

Thompson DR, Furness RW (1995) Stable-isotope ratios of carbon and nitrogen in feathers indicate seasonal dietary shifts in northern fulmars. Auk 112:493-498

Thompson DR, Furness RW, Walsh PM (1992) Historical changes in mercury concentrations in the marine ecosystem of the north and north-east Atlantic ocean as indicated by seabird feathers. J Appl Ecol 29:79-84

Thompson DR, Hamer KC, Furness RW (1991) Mercury accumulation in great skuas Catharacta skua of known age and sex, and its effect upon breeding and survival. J Appl Lcol 28:672-684

Walsh PM (1990) The use of seabirds as monitors of heavy metals in the marine environment. In: Furness RW, Rainbow PS (eds) Heavy metals in the marine environment. CRC Press Inc, Boca Raton, p 183-204

Warham J (1996) The behaviour, population biologfy and physiology of the petrels. Academic Press, London

Watras CJ, Bloom NS (1992) Mercury and methylmercury in individual zonnlankton implirations for bioaccumulation. Limnol Oceanogr 37:1313-1318

Wilson RP (1984) An improved stomach pump for penguins and other seabirds. J Field Ornithol 55:109-112

Windom H, Gardner W, Dunstan DM, Paffhenofer GA (1976) Cadmium and mercury transfer in a coastal marine ecosystem. In Windom HL, Duce RA (eds) Marine pollution transfer. Lexington Books, p 135-157

Zar JH (1984) Biostatistical analysis, 2nd edn. Prentice-Hall International, Englewood Cliffs, NJ

Submitted: November 7, 1997; Accepted: February 6, 1998 Proofs received from author(s): May 4, 1998 